\title{
JOURNAL WRITING: A TECHNIQUE TO ENHANCE SELF ESTEEM OF THE PROSPECTIVE TEACHERS
}

\author{
Dr. Archana V Katgeri \\ Assistant Professor, Hansraj Jivandas college of Education, Khar (W), Mumbai, India
}

Article DOI: https://doi.org/10.36713/epra7124

DOI No: 10.36713/epra7124

\begin{abstract}
NEED
Teachers are the pillars of education system. They are in direct contact with the young students on day-to-day basis who can be moulded and shaped in the right way at an impressionable age. Teachers have a phenomenal influence on the minds of the students. Teachers' well-being has a great impact on students' well-being. Thus, it is imperative for the teachers to hold high self-esteem as they are the role models for their students. Also, in turn they can successfully prepare the students in developing positive self-esteem. Hence training the prospective teachers in ways to build high self-esteem is the need of the hour. With this objective in mind an experimental study was conducted to enhance the selfesteem of the prospective teachers. An intervention program was put into effect which included the technique of journal writing to enhance the self-esteem. The major findings of the study showed that the intervention program has brought a remarkable change with respect to the self-esteem of the prospective teachers. The journal writing technique has helped the participants to critically reflect on their thoughts, views, beliefs, and actions. Thereby giving them an opportunity to bring a change and improvement in their future behaviour.
\end{abstract}

KEY WORDS: - Journal writing, Self Esteem, Prospective Teachers.

\section{INTRODUCTION AND CONTEXTUAL BACKGROUND}

The fast changes in today's world present new challenges and greater demands on our education system. Thus, it has become a necessity to change and improve the preparation of the prospective teachers to function efficiently in the field of education. It is seen that and individual's performance to a great extent is determined by his or her personality. Personality is the typical pattern of thinking, feeling, and behaviours that make a person unique. When we say that someone has a good personality, we mean that they are friendly, interesting, and pleasant to be with. Each person wants to be charming to others. Also, approximately 85 percent of your success and happiness is basically a result of good interpersonal skills. Personality comprises of our self-concept and self-concept is made up of our self-esteem and our self-image. Selfconcept is the sum of the ways in which we think about ourselves and self-esteem is referred to as how highly we think about our abilities and our self.
The word esteem means that someone or something is important, special, or valuable. Self means you. So, Self-Esteem refers to the extent to which we like accept or approve of ourselves or how much we value ourselves. It involves a degree of evaluation and we may have either a high or a low self- esteem of ourselves. Persons with high selfesteem have a positive view of themselves. Thus, they have better confidence in their own abilities' ad potential. They accept themselves the way they are without worrying much about what others think of them. These individuals have an optimistic outlook towards life and can perform competently in their work.

Persons with low self-esteem have a negative view of themselves. Thus, they lack confidence in their own abilities and potential. They always keep comparing themselves with others and want to be like them. Most of the time they suffer from inferiority complex and are not ready to accept the way they are. This in turn lives them with a pessimistic attitude towards life and are constantly 
under the fear of not being able to perform efficiently in any endeavors in life.

While we can only enhance our looks to a certain extent, but definitely it is possible to improve one's personality as much as we want.

William James is believed as the creator of the self-esteem movement. According to James selfesteem is equal to success divided by our pretensions. Pretensions refer to our goals, values, and our belief about our potential. It is observed that if our level of success exceeds our expectations, then we might view ourselves as successful and feel good about ourselves, which automatically raises our selfesteem. On the other hand, if our achievements do not meet our expectations, then we may see ourselves as a failure and tis will tend to lower our self-esteem. Stanley Coopersmith has significant contribution in the study of self-esteem. He believed that self-esteem begins early in life in childhood. According to Coopersmith our self-esteem builds up, or declines throughout our lives, based upon our early childhood experiences, which may be positive or negative. Morris Rosenberg, a contemporary of Coopersmith, also studied self-esteem. His study focussed on the development of self-esteem in the adolescent years. Another renowned psychologist Rosenberg believes that self-esteem develops more in the adolescent years. His theory of self-esteem was based upon the premise that during adolescence, we often compare ourselves to others, which causes us to continually evaluate and re-evaluate how others see us or think about us. Thus, these theories are based more on the role our self-esteem plays in our lives and on our psychological well-being.

\section{Rationale of the study}

Self-esteem is a passport for success in life. In today's materialistic and competitive world everyone wants to be at the top. A lack to self-esteem means less confidence in your abilities and chances of failure are more. The individual is not able to make right decisions and mostly is controlled by others. A teacher needs to have high self-esteem as they are the role models for their students. Thus, it is important to train the prospective teachers and make them proficient to cater to the needs of the students. With this objective in mind an experimental study was conducted to enhance the self-esteem of the prospective teachers.

\section{Statement of the Problem}

The problem of the study focusses on developing a program to enhance the self-esteem of the prospective teachers and studying its effectiveness.

\section{VARIABLES OF THE STUDY}

\section{Dependent variable}

Self-esteem

\section{Independent variable}

Intervention program to enhance the self-esteem of prospective teachers.

\section{Operational Definitions}

Self-esteem: For the present study, self-esteem is defined as an ability of the individual to value and respect oneself.

Journal writing: For the present study, is defined as a technique for reflecting on the daily actions, thoughts, feelings and thinking.

Prospective teachers: For the present study, is defined as soon to be teachers who are currently undergoing the two-year B.Ed. program offered by Mumbai University.

\section{Objectives of the study}

1) To conduct a pretest to know the self-esteem of the prospective teachers at the start of the program.

2) To develop an intervention program to enhance the self-esteem of prospective teachers.

3) To study the effectiveness of the intervention program on prospective teachers in terms of

i. Increasing their self esteem

ii. Better understanding of self.

4) To conduct a posttest to know the selfesteem of the prospective teachers at the end of the program.

5) To find the difference in the pre and posttest to measure the self-esteem of prospective teachers.

\section{Hypothesis of the Study}

1) There is no significant difference in the pre-test and post-test scores on self-esteem of the prospective teachers after the implementation of the intervention program.

\section{Scope and Delimitations of the Study}

The present study focuses only on enhancing the selfesteem of the prospective teachers from Hansraj Jivandas College of Education.

\section{Method of the study}

For the present study, single group pre-test -post-test experimental design is used to test the effectiveness of the intervention program to enhance the selfesteem of prospective teachers. Pre-test was administered before the application of the treatment variable and post-test at the end of the treatment variable. Pre-test and post-test scores were compared and subjected to test of significance of the difference between the means of two tests.

The single group pretest-posttest design is represented as follows:

O1 X O2

Where $\mathrm{O} 1$ is the pretest 
$\mathrm{O} 2$ is the posttest

$\mathrm{X}$ is the treatment variable

Sample and Sampling Technique

For the present study, the population comprises of 50 students of first year Bachelor of education college in Mumbai who are the prospective teachers. The sample was selected by incidental sampling technique.

Tools for the Data Collection

Rosenberg Self-esteem scale: A 10-item scale that measures global self-worth by measuring both positive and negative feelings about the self. The scale is believed to be uni-dimensional. All items are answered using a 4-point Likert scale format ranging from strongly agree to strongly disagree.

Scoring Key: The scoring for the self-esteem tool is as follows: -

Items 2, 5, 6, 8, 9 are reverse scored. Give "Strongly Disagree" 1 point, "Disagree" 2 points, "Agree" 3 points, and "Strongly Agree" 4 points. Sum scores for all ten items. Higher scores indicate higher selfesteem.

The intervention program was developed by the researcher to enhance the self-esteem of the prospective teachers. The researcher developed the intervention program based on the ADDIE model which consists of five phases: Analysis, Design, Development, Implementation and Evaluation.

For the experimental study, the data was collected from 50 student teachers for over a period of one month. Before commencing the program, pre-test was administered to measure the level of self-esteem and at the end of the program the post-test was administered to measure the same.

Inferential analysis: - The statistical technique used was the t-test for testing the following hypothesis:

There is no significant difference in the pre-test and post-test scores on self-esteem of the prospective teachers after the implementation of the intervention program.

\section{MAJOR FINDINGS}

\section{Hypothesis:}

The hypothesis testing was done by using Single group ' $t$ ' test to check the effectiveness of the intervention program to enhance the self-esteem of the prospective teachers.

Testing of the hypothesis 1

There is no significant difference in the pre-test and post-test scores on self-esteem of the prospective teachers after the implementation of the intervention program.

The statistical technique used to test this hypothesis was Single Group 't' Test

TABLE 1.1

DIFFERENCE IN THE PRE-TEST AND POST-TEST SCORES FOR CC

\begin{tabular}{|c|c|c|c|c|c|c|}
\hline $\begin{array}{c}\text { Single } \\
\text { Group }\end{array}$ & N & Mean & SD & $\begin{array}{c}\text { Obtained t- } \\
\text { ratio }\end{array}$ & $\begin{array}{c}\text { Tabulated t- } \\
\text { ratio }\end{array}$ & l.o.s \\
\cline { 1 - 3 } Pre-test & 50 & 28.38 & 4.20 & \multirow{2}{*}{6.73} & 2.75 & 0.01 \\
\cline { 1 - 4 } Post-test & 50 & 33.6 & 3.05 & 6.73 & \\
\hline
\end{tabular}

\section{Interpretation}

Table 1.1 shows the obtained ' $t$ ' is greater than the tabulated ' $t$ '. Hence the null hypothesis is rejected. There is a significant difference in the pre-test and post-test scores on self-esteem of the prospective teachers after the implementation of the intervention program.

Conclusion: There is significant difference in the pre-test and post-test scores of prospective teachers' self-esteem. The post-test mean score is higher than the pre-test score of the group. This implies that the intervention program has helped in enhancing the self-esteem of the prospective teachers.

Discussion: In the present study the intervention program has brought a remarkable change with respect to the self-esteem of the prospective teachers. The journal writing technique for a period of one on daily basis has helped the participants to critically reflect on their thoughts, views, beliefs, and actions. Thereby giving them an opportunity to bring a change and improvement in their future behaviour.

\section{Observations and reflections by the researcher}

The participants wanted to know their level of self-esteem. The pretest was conducted and the scores for self-esteem was obtained. Later the participants were oriented to the activity of journal writing on daily basis for a period of one month. Initially they were little hesitant in expressing their true feelings. But by the end of first week, they realized the importance of pouring their hearts out in form of the journal writing. They could see the change in their thought process and their behavior. As the program progressed, participants showed interest in the activity of maintaining the journal. By 
the end of second week the students came and conveyed how happy they were with this activity and the positive change that they and others around them noticed. The students who otherwise were always dependent on others for making decisions, had started taking decisions for themselves. Few students also shared that the activity has helped them to a great extent to have a control over their anger and thereby improved their interpersonal skills. The researcher observed that slowly the participants developed more respect and self-acceptance. Few participants were very rigid and reluctant when it came to detailing their thoughts on daily basis but eventually, they also changed their attitude and wholeheartedly participated in the activity. The participants were adults and mature enough to understand the purpose of such programs. The researcher could see the activities helped the participants to know themselves better in terms of their capabilities and potential. Towards the end of the program the participants expressed that the one-month challenge compelled them to revisit their daily life and realize what is important. They were willing to continue this journal writing even after the experiment is over as it has brought tremendous change in them and has developed their self-confidence, helped to enhance their writing skills and also proved to be extremely liberating and relaxing way of calming down the unstable mind. Thus, the researcher is of the opinion that such techniques should be conducted on regular basis with the teachers as it gives some time from the routine mundane tasks to think, reflect and introspect the various situations in and outside the classroom which is very important to bring a positive change in the socio emotional climate and make a conducive environment for learning. At the outset, the researcher was very satisfied with the outcome of the intervention program.

\section{Implications of the Study}

Self -esteem plays a very important role in the personality development of the individual. Having Low self-esteem may prove to be a great barrier in the life, hence having a high self-esteem is the need of the hour. Therefore, the techniques for enhancing the self-esteem occupy a pivotal position in one's life. There are different ways and techniques which need to be introduced to the prospective teachers for developing self-esteem. So that these teachers will later train the young generation to follow good practices in life which will induce a positive change in them and make them a better person to handle the challenges in their personal life and as a student also. The B.Ed. program which is meant to train the prospective teachers should have such activities included in the curriculum.

Also, workshops can be arranged for inservice teachers so that they are oriented to the importance of maintaining high self-esteem for their profession.

\section{CONCLUSION}

Journal writing on daily basis facilitates in taking care of our mental wellbeing. Taking out some quality time from your daily routine and spending time with your own thoughts and feelings has a myriad of benefits. Journal writing will help a person to work through the problems and allows you to look at the situation objectively. It helps you to reassess the situations and when you are faced with similar situation in future, the person is in a better position to handle it without getting stressed, frustrated, and running away from it. A person with high selfesteem is open minded and ready to accept the challenges in life. Teachers with high self-esteem know about their teaching capabilities and find it easy when it comes to handling the diverse population in the classroom. They are highly enthusiastic and full of positivity and pass on the same to people around them. These teachers may also be able to rebound from setbacks and more willing to experiment with new ideas and techniques in the teaching-learning process. On the other hand, teachers with low self-esteem may rely more on controlling teaching style and are very critical in their approach which is not healthy when interacting with the students. Thus, holding high self-esteem is a prerequisite for a teacher.

\section{REFERENCES}

1. Dandapani,S.(2001). A Text Book of Educational Psychology.New Delhi.Anmol Publication Ltd.

2. Dandekar,W.N.(1998). Psychological Foundations of Education.New Delhi. MacMillan India Ltd.

3. Mangal,S.K(2007).Educational Psychology. New Delhi, Prentice hall of India.

4. Best, J.W. \& Kahn, J.V. (2006) Research in Education. New Delhi: Prentice Hall of India Private Limited, tenth Edition.

5. Creswell (2012) Educational Research, Fourth Edition PHI Learning pvt ltd, New Delhi.

6. Garette,H (1996) Statistics in Psychology and Education, Bombay: Vaklis Feiffer and Simons ltd.

7. UNESCO, 2002. Learning to be a holistic and integrated approach to values education for human development: UNESCO-APNIEVE sourcebook 2 for teachers, students and tertiary level instructors. UNESCO, Bangkok, retrieved from

http://unesdoc.unesco.org/images/0012/001279/1 27914e.pdf

8. Self-esteem: Why it's important. retrieved from http://www.mdhil.com/self-esteem-importancel

9. The story of self-esteem. retrieved from http://kidshealth.org/kid/feeling/emotion/self_este em.

10. Riopel, Most Effective Self-Esteem tools and Activities. retrieved from https://positivepsychology.com/self-esteem-toolsactivities/ 